Article

\title{
De Anima: Or, Ulysses and the Theological Turn in Modernist Studies
}

\author{
David Ayers \\ School of English, University of Kent, Canterbury CT2 7SE, UK; dsa@kent.ac.uk \\ Received: 1 June 2017; Accepted: 28 July 2017; Published: 4 August 2017
}

\begin{abstract}
Focusing on Joyce's use of Aristotle's De Anima, and on Aquinas's response to Aristotle, this essay takes, as its starting point, the recourse to two areas of enquiry in recent work on modernism: animal studies and phenomenology. In this essay we examine the intersection within Ulysses of the concept of the soul in Aristotle and Aquinas, show how this relates to questions of animality, and open the way to asking what implication the theological reflection on the soul at the centre of Ulysses might have for a process of uncovering theological contents in the concept of "life" in modernist studies more generally.
\end{abstract}

Keywords: soul; anima; psyche; Joyce; Ulysses; Aristotle; Aquinas; Heidegger; Derrida

On perçoit la structure dans l'instance da la menace, au moment où l'imminence du péril concentre nos regards sur la clef de voûte d'une institution, sur la pierre où se résument sa possibilité et sa fragilité. On peut alors menacer méthodiquement la structure pour mieux la percevoir, non seulement en ses nervures mais en ce lieu secret où elle n'est ni érection ni ruine mais labilité.

(Derrida 1963, p. 15)

This essay proposes an amplification of the concept of anima or soul as it transects Ulysses. Soul in Ulysses evokes the long duration of the history of its concept in Aristotle and Aquinas. Ulysses does not advance a single concept of soul, but loosely sets in play a confrontation of the Aristotle-Aquinas axis favoured by Stephen and the vision of transmigratory souls embodied in so many aspects of the text. The main thread in this essay compares Aristotle and Aquinas, showing how the contrast between their conception of the soul in relation to animality is at play in Stephen's reflections on De Anima and its Thomistic commentary, and goes on to argue that Aristotle's own vision of a human-animal continuum is continuous with the ethos of Ulysses.

The starting point for this train of thought is the recourse to two areas of enquiry in recent work on modernism: animal studies and phenomenology. The subtitle echoes the title of Dominique Janicaud's essay, Le tournant théologique de la phénoménologie française (Janicaud 1991), which was collected with essays related to that theme by Michel Henry, Jean-Luc Marion and others as Phenomenology and the Theological Turn: The French Debate (Janicaud et al. 2000). The theological turn in French phenomenology was explicit, as technically titled studies such as Henry's L'essence de la manifestation (Henry 1963) and Marion's Étant donné (Marion 1997) were complemented by works with an explicitly theological dimension, such as Henry's C'est moi la Vérité (Henry 1996), and Marion's Dieu sans l'être (Marion 1982). We might be mindful too of the discussion on religion into which Gianni Vattimo led Jacques Derrida in a 1994 seminar, published as La Religion: Séminaire de Capri (Derrida and Vattimo 1996).

This "theological turn" which Janicaud opposed in the work of Henry, Marion and others was not a hidden secret, but to suggest that there can be a theological turn in modernist studies is to ask a more complicated question about the motive and provenance of certain lines of inquiry, and to ask 
whether such inquiries, which depend inevitably on their objects, are inextricably theological in terms of the sedimented intellectual histories both of the oeuvres in question and of the methodologies. The simplest way to present this is to ask whether animality and phenomenality are always questions about the nature of life, and whether the question "what is life", a question that has the appearance of being an ethical question in terms of its practical applications, has a theological dimension which may be inescapable. In relation to Joyce, this line of questioning leads to something a little different to the questions of belief and religion tackled in recent scholarship (Tonning 2014; Lernout 2010) and adds an unanticipated dimension to the recent convergence of Joyce and animal studies (Mak 2016; Norris 2014).

The references to Aristotle's De Anima in Ulysses are well known. De Anima and its companion De Sensu are referenced in the famous opening of "Proteus" where Stephen Daedalus contemplates the workings of visibility:

Limits of the diaphane. But he adds: in bodies. Then he was aware of them bodies before of them coloured. How? By knocking his sconce against them sure. (Joyce 1992, p. 45)

The first part of this_-"limits of the diaphane" — cites Aristotle. The question about the relationship between bodies and light is Stephen's, and goes to the core of Aristotelian metaphysics, which distinguishes between substance and qualities (it is in a nutshell the critique of metaphysics), and the final part about knocking against the body invokes the seeming common-sense of Bishop Berkeley's famous supposed refutation of metaphysics in the kicking of a stone. The palette here is the relationship between mind, senses and the body, and the lightest implicit questioning of the Aristotelian conception of a body as entelechy or actualised potential. This questioning-once taken as little more than evidence of Stephen's detached intellectualism-is set against the following page where Stephen contemplates the midwives. He considers the linkage between bodies throughout time- "The cords of all link back, strandentwining cable of all flesh" - and imagines a telephone call back to his Edenville in possibly the most striking figurative use of the telephone in literature. Without saying more about the further references to theology in this passage, it is easy to see that the animal body and its dual nature, as part end in itself and part continuous organic process, is being established here as a general theme of Ulysses. This is well enough known, I think, so all I am proposing here is to re-inflect some of the ways we can think about this.

Readers of Ulysses know that one guiding structure of the book is the opposition between Stephen as mind and Bloom as body. Each of the Bloom chapters is associated with a bodily organ while Stephen's three chapters are not. This led many early commentators to find that the novel celebrated the body of the everyman Bloom as opposed to the purportedly effete mind of Stephen. It has always been my reflection that the mind which formed Ulysses was that of a Stephen Daedalus, not that of a Bloom but, whatever values we decide to invest in the Stephen-Bloom opposition, it is clear that the nature of mind and body is thematised throughout the text. Joyce's use of Aristotle and Aquinas gives important clues to the philosophical and theological motivations of this device.

Joyce had read Aristotle's De Anima and De Sensu, as well as the Metaphysics, in Paris in 1903, alongside Aquinas's commentaries on those texts, although some further research is needed to confirm the accepted details of Joyce's reading (the starting point is Noon 1957). Joyce also read Aristotle's poetics - which was not known to Aquinas and which he did not comment on-and the influence of this, as well as commentaries on it by Bernard Bosanquet and Samuel H. Butcher, on the aesthetic discussion of Stephen Hero and Portrait are not only well-known (see (Schork 1998, pp. 157ff; O'Rourke 2011)), but have probably tended to dominate our accounts of the importance of Aristotle and Aquinas for Joyce. De Anima though plays a large part in Joyce's work as is revealed not only by the quotations from that work, but also by the role played by the notion of soul in Ulysses.

We should remind ourselves at this point that the Greek title given to Aristotle's work is Peri psuches, given in Latin as De anima and in English as On the Soul. The trajectory of the terms psyche and anima does not entirely resemble that of some of the other philosophical terms which 
were rendered into Latin, but the context of revisiting such transferences is always the claim made repeatedly by Heidegger regarding the eclipse of Greek philosophy, for example in his Introduction to Metaphysics, as he explains the shift that takes place from Greek phusis to Latin natura:

But with this Latin translation, the originary content of the Greek word phusis is already thrust aside, the authentic philosophical naming force of the Greek word is destroyed. This is true not only of the Latin translation of this word but of all other translations of Greek philosophical language into Roman. This translation of Greek into Roman was not an arbitrary and innocuous process but was the first stage in the isolation and alienation of the originary essence of Greek philosophy. The Roman translation then became definitive for Christianity and the Christian Middle Ages. [...] But now we leap over this whole process of deformation and decline [... . (Heidegger 2000, pp. 14-15)

In the context of psyche/anima, however, and without intending any intervention in Heidegger's general account of philosophical loss and forgetting, we should note that to the modern ear the term psyche is more associated with mind, which it is not, and which in Greek is nous, although in De Anima intellect seems to be described as a faculty of the soul, alongside nutrition, sense-perception, imagination and motion. Equally, anima to the modern ear recalls the "animal" or "animality"-which indeed it fairly literally does mean, even though plants are said by Aristotle to have one faculty of the soul, they are affected by touch (Aristotle 1957, p. 137), and would not be classed by us now as animals. It also recalls animation, and again the etymological connection is pretty direct, but what none of these anima-derived modern terms allow for is the notion of the soul as the governing form. In any case, the major conflict which transects the term psyche does not really stem from its Latin translation but from the contestation about the immortality of the soul which is found in Plato not just in the Medieval reception of Aristotle, or indeed its transferability, which is found in Pythagoras (though not of course in Aquinas). What is clear, is that the terms psyche and anima refer to the most fundamental principle of life, its very form, and that which, in modern terms, animates it.

We are going to examine whether and how differing meanings or valences of the term soul are important for the manner in which Ulysses sets in play differing models of the life process. Aquinas knew De Anima not as we might expect from a Greek text but from a new translation by William of Moerbeke, and produced a commentary (Sentencia libri De anima) in 1267-1268, and in the same time-frame wrote Sections 75 and 76 of the Summa Theologiae (1266-1273) which deal with the relationship between soul and body. Heidegger famously refers us to the slippage between the philosophical language of Ancient Greece and its Latin translations, urging a recovery of the forgotten question of being, but in the case of psyche/anima there is not so much a slippage as an appropriation. There is a tension between the Aristotelian view of the psyche as the form of the body, and the treatment of the anima as an eternal form (on Platonic lines) by Aquinas (but not by his predecessors Avicenna and Averroes). This distinction touches, at least in passing, on the claim I am testing here concerning the "theological" in modernism. That there are different ways of thinking about this philosophical/theological split can be exemplified by comparing the approaches of one commentator on Aristotle and one on Aquinas, respectively. The Aristotle scholar claims that, while the rise of Aristotelianism in Christian Europe between the early twelfth century and the mid-fourteenth century was "one of the great revolutions in intellectual history", the study of De Anima in the millennium up to and including Aquinas was "vitiated by being preoccupied with a question of only secondary interest to Aristotle [...] the nature of the soul's immortality" (Lawson-Tancred 1986, p. 100). In contrast, the commentator on Aquinas draws a strict distinction between the theological passages of the Summa Theologiae, declaring that "for Thomas, philosophy and theology are sciences which differ generically (secundum genus), even if they often bear on the same 'material' objects" (Bazán 2016, p. 15. My translation) and distinguishes between Questions 67-74 of the Summa, which deal with the creation and are therefore principally of theological interest, and the treatment of the soul which belongs to Thomas's anthropology and psychology. Nevertheless, Bazán notes the interference of the theology with the philosophical character of Thomas' anthropology: 
Thomas maintains that the human being possesses the most perfect degree of life and for this reason its life (its soul, breath) is not produced by the earth like that of other animals but directly by God. This theological thesis, which for Thomas means that God immediately created the soul of every human being, is the cornerstone of his conception of being and puts into question the properly philosophical nature of his anthropology. (Bazán 2016, p. 11. My translation)

This idea of a conflict between the Aristotelian and Thomistic concept of the creation of the individual helps account for the thoughts which run through Stephen's mind after his vision of the midwives in Proteus. Stephen contrasts his animal creation ("They clasped and sundered, did the coupler's will") to Thomas' version of the divine creation of his soul ("From before the ages He willed me and now may not will me away or ever") (Joyce 1992, pp. 46-47). Thomas asserts:

Respondeo dicendum quod necesse est dicere animam humanam, quam dicimus intellectivum principium, esse incorruptibilem. [...] Ostensum est autem supra quod animae brutorum non sunt per se subsistentes, sed sola anima humana.

Solution: it is necessary to say that the human soul, which we say is an intellective principle, is incorruptible. [...] We showed above that the souls of animals are not self-subsistent, only the human soul. (Summa Theologiae q. 75 a. 6, cited from (d'Aquin 2016, p. 140). My translation)

The soul as the form of the finite individual animal in Aristotle and the eternal soul of Aquinas sit in uneasy conjunction in Thomas' work. Ulysses adds to this optic of the individual animal the vision of a continuous engendering, which severely puts in question the notion of the individual as an end in itself. This is one sense anyway conveyed by Stephen's vision of the "strandentwining cable", and it is this vision of organic life as a process of creation and obliteration which is offset by Stephen's reference to De Anima in Nestor, where he recalls Joyce's own reading in the library of Saint Geneviève in Paris: "Thought is the thought of thought. [...] The soul is in a manner all that is: the soul is the form of forms." (Joyce 1992, p. 31) This can be connected to the often cited line in Scylla and Charybdis, in the discussion about Shakespeare's father in the library, when Stephen at first idly entertains the notion that due to changes in molecules he is no longer the same " $\mathrm{I}$ " who owes A.E. a pound, but then shifts to the more serious gear that generally accompanies reference to Aristotle in Joyce as he again reflects on De Anima: "But I, entelechy, form of forms, am I by memory because under everchanging forms." (Joyce 1992, p. 242)

We should reiterate that psyche and nous, soul and mind, are not the same thing in Aristotle's account. This matters for our account too, since the claim that there should be a hitherto unarticulated theological turn in modernist studies depends on an admittedly distant parallel between the Aristotelian psyche and what Michel Henry calls life or "la vie". Psyche is the enabling structure or ground of nous - that is, soul and mind are not the same thing, or if they are-and De Anima may be a touch equivocal here-mind in its knowing is the "form of forms". For illustrative purposes, and without being able to do more than anticipate an argument with many phases, we can refer here to Henry's essay "Le concept de l'âme a-t-il un sens?" (1967, partially revised for publication shortly before his death, and published posthumously in (Henry 2003)) - does the concept of soul mean anything? Henry advances the term "life" throughout his work so reference to the soul in this essay is not an attempt to re-establish Aristotle, who in any case figures very little in Henry's work which takes its impetus mainly from Husserl and Heidegger. Henry approaches the question of the soul by invoking Kant and rational psychology as its opponents:

We ask this question because, between traditional metaphysics, which tells us that we have a soul, that this soul is a substance-spiritual, simple, self-identical through time-the existence of which is distinct from that of the body and is therefore not perishable-between this metaphysics, reassuring if you like, and us, there is the philosophical critique of the eighteenth century, and in particular the critique of Kant, which considered itself to be radical and definitive. (Henry 2003, p. 8. My translation.) 
The critique of Kant is that "the structure of being, as Kant understood it, is incompatible with the structure of being of our 'me'. This structure of being of 'me' we call the essence of ipseity" (Henry 2003, p. 15). The argument, which cannot be detailed here, is that internal experience as described by Kant can never make the "me" available to intuition, and that when Kant talks of the "me" he never takes account of the "ipseity" which makes it possible. Henry indicates a trajectory which goes from the Thomistic soul, via its radical critique in the form of rational psychology, to the challenge to Kant by the philosophy of Being. He touches on Heidegger and Merleau-Ponty and might, had he concluded his revision of the piece, looped it back into the later developments in his own work on the concept of life as auto-donation and Archi-intelligibilité, in terms which arise within a convergence of philosophy and theology in the model of life as incarnation, an end and good in itself (Henry 2000, pp. 361-73).

Henry's search for "life" bypasses Aristotle, but by contrast entelecheia receives a wonderful gloss in Heidegger which, as it is read, seems almost enough to counter the anti-teleological consensus of recent decades, and gives strong poetic shape to the notion of end or telos:

The self-restraining hold that comes from a limit, the having-of-itself wherein the constant holds itself, is the Being of beings; it is what first makes a being be a being as opposed to a nonbeing. For something to take such a stand therefore means for it to attain its limit, to de-limit itself. Thus a basic characteristic of a being is its telos, which does not mean goal or purpose, but end. Here "end" does not have any negative sense, as if "end" meant that something can go no further, that it breaks down and gives out. Instead, "end" means completion in the sense of coming to fulfilment (Vollendung). Limit and end are that whereby beings first begin to be. This is the key to understanding the highest term that Aristotle used for Being: entelecheia, something's holding-(or maintaining)-itself-in-its-completion-(or limit). [...] Whatever places itself into and thereby enacts its limit, and thus stands, has form, morphē. The essence of form, as understood by the Greeks, comes from the emergent placing-itself-forth-into-the-limit. (Heidegger 2000, p. 63)

Heidegger's rhapsodic celebration of entelechy here is an interpretation of the sense of the term in Aristotle rather than a literal account of the Metaphysics. His confirmation of its centrality helps to show why it might be that the term runs through Stephen's mind either as an affirmation or as a doubt (the reader is not given a firm steer). We should remind ourselves though that Aristotelian entelechy is actualised as much in the life of the dog (which Stephen wishes to distinguish from his own life in Proteus) as in a human life. Aristotle expresses the matter a little more drily in De Anima:

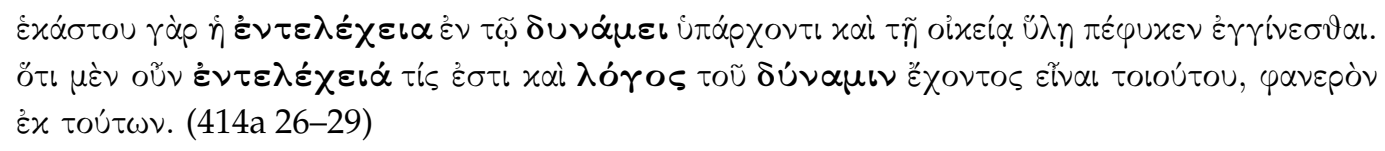

for the actuality of each thing is naturally inherent in its potentiality, that is in its own proper matter. From all this it is clear that the soul is a kind of actuality or notion of that which has the capacity of having a soul. (Aristotle 1957, p. 81; emphasis added)

Stephen's musing in any case compresses the notion of entelechy with his earlier reflections in Nestor on the discussion of mind in De Anima. Each notion is critically important, of course, and they are not unrelated, since the distinction between mind and soul is central for any sense of how a notion of life is to be grounded.

The reference to mind as $\varepsilon$ i $\delta$ o $\sigma i \delta \widetilde{\omega} v$, form of forms, comes in a key passage of De Anima which greatly amplifies the notion of soul beyond the conception of it as the form of the actualised entity:

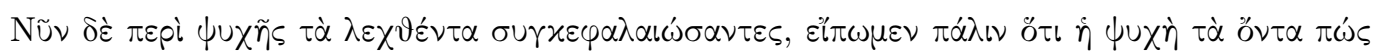

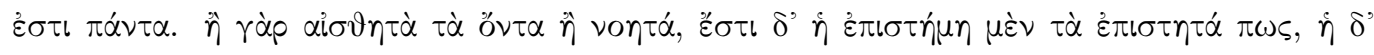

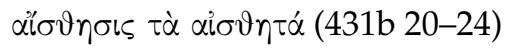


Now summing up what we have said about the soul, let us assert once more that in a sense the soul is all existing things. What exists is either sensible or intelligible; and in a sense knowledge is the knowable and sensation the sensible. (Aristotle 1957, p. 178)

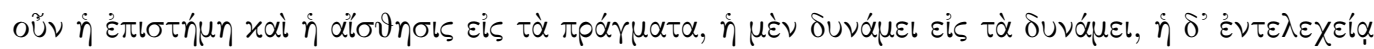

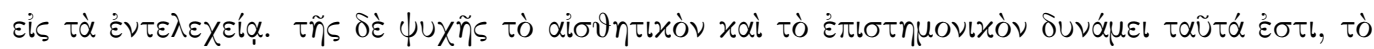

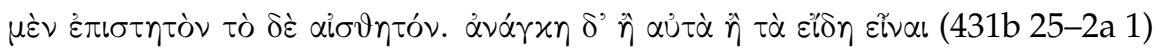

Both knowledge and sensation are divided to correspond to their objects, the potential to the potential, and the actual to the actual. The sensitive and cognitive faculties of the soul are potentially these objects, viz., the sensible and the knowable. These faculties, then, must be identical either with the objects themselves or with their forms. (Aristotle 1957, pp. 178, 180)

Noting that perception and its object are not the same thing, since the (perceived) stone does not itself exist in the soul (psyche), but only its form (eidos), Aristotle continues:

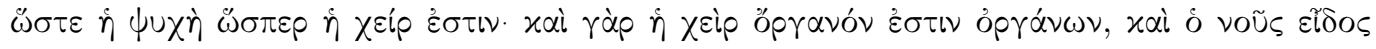

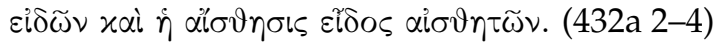

The soul, then, acts like a hand; for the hand is an instrument which employs instruments, and in the same way the mind is a form which employs forms, and sense is a form which employs the forms of sensible objects. (Aristotle 1957, p. 180)

This is the passage Stephen has recourse to in Nestor when he muses that "Thought is the thought of thought. [...] The soul is in a manner all that is: the soul is the form of forms." These formulations do rewrite De Anima, as "thought" is used to stand for nous/mind and eidos/form, and it is not said that soul is the form of forms. It is odd perhaps that it is not said, as Aristotle introduces a metaphor at a crucial juncture, by comparing the soul to a hand which uses tools-an organon of organa. This leaves open the question whether the faculties of the soul, mind and sensation, are the soul, or whether they belong to it. One commentator glosses this passage as follows:

The hand is an instrument employed by the soul to utilize various further instruments to accomplish all sorts of tasks. [...] The power of sense and the power of knowledge are forms put to use by the soul for cognizing intelligible and sensible things by way of their cognizable forms. These cognitive faculties are forms since each is a definite capacity receptive of the cognitive forms in its domain. By means of these powers put over cognizible forms the soul cognizes all the things that are there to be sensed and known. (Polansky 2007, p. 496)

The slippage in the commentary here arises from an aporia in the thinking. Form is always form of, never content. To introduce the metaphor of the hand strongly signals the difficulty. If the hand instrumentalises tools - the organ of organs-in what sense can it be said that the soul instrumentalises the hand? (We can merely allude here to the role played by the hand in the work of Heidegger, and Derrida's essay on that topic, (Derrida 1987)) If mind and sense "cognise" the world what does it mean to say that thereby the soul "cognises"? Does the soul instrumentalise mind as the hand instrumentalises tools? To what end and from what motive? Perhaps it is hard to grasp Aristotelian eidos as in any way different from what we might call form or structure, but even if this makes a difference, there is a plain contrast between the notion of the soul as cognising as the mind does but through the mind and the other senses, and the notion of the soul as the formal ensemble of all components making up the animal, or plant.

Aquinas seems to have identified this problem and attempted to resolve it in a model which sets the soul as the first principle of being (entelechy), in which capacity it is the compound of living being, 
animal, and human being. The soul is also the potentia or vital energy, which is the principle of the nutritive, sensitive and intellective operations-these later powers are the intermediaries of the soul and can conduct their separate operations which the soul cannot. The soul can be conceived without them but it cannot be conceived as existing without them (d'Aquin 2016, pp. 75-76). Despite this distinction, when Thomas tackles the issue of the stone-it is always a stone, by the way, for reasons that are in themselves interesting - he uses the expression "anima intellectiva" (Summa Theologiae q. 75 a.5; (d'Aquin 2016, p. 136)), reiterating Aristotle's conclusion that "anima igitur intellectiva est forma absoluta" [the intellective soul is an absolute form], but in terms of the phrase he has chosen, at least, blurring the distinction once again between the soul and its faculties, though it remains clear that although the soul participates in the "prima materia", the potentiae do not. Yet Thomas has already asserted that the soul is intellective and the awkward relationship between soul and mind continues to skitter.

Despite the elusiveness of attempts to define the soul as the very essence of life, especially but not exclusively around the question of its relation to mind and (as Henry's essay outlined) the question even of the possibility of its being present to mind, the first part of this section of De Anima retains its stunning suggestiveness. The assertion that the soul is "all things" gives the fullest meaning to the notion of "form of forms". Without investigating every alleyway or indeed freeway which this phrase seems to open, we can note at least how this notion of soul connects the individual animal to the whole world of the living and unliving and in principle allows the opening of all the areas of thought which the biologist's attention to the individual being had bracketed. This phrase too could stand as an epigraph to the encyclopaedism of Joyce's project in Ulysses and the Wake.

So having with a little patience presented some elements of the role of De Anima in Ulysses, we can now turn to one or two other appearances of the soul in the text. It is plain from the first page of Ulysses, where Mulligan parodies the mass, that the relationship between soul and body is in question: "For this, O dearly beloved, is the genuine Christine: body and soul and blood and ouns [wounds]." (Joyce 1992, p. 1) Mulligan's materialism has been the spur to Stephen's pondering on the soul in Nestor which is offset in that same chapter by the conclusion of the riddle Stephen sets-“"Tis time for this poor soul/To go to heaven" (Joyce 1992, p. 32). The afterlife of the soul is raised again when Molly, without even saying the word, asks her husband the meaning of metempsychosis. Bloom reads it out for himself:

Metempsychosis, he said, frowning. It's Greek: from the Greek. That means the transmigration of souls. (O, rocks! she said. Tell us in plain words. (Joyce 1992, p. 77)

Bloom does not immediately reply. Instead his thoughts wander off in denial into the book Molly has shown him, then rebound suddenly:

That we live after death. Our souls. That a man's soul after he dies. Dignam's soul. (Joyce 1992, p. 78)

The reply when it comes is neutral and factual, concealing the spiritual shiver that reference to death had brought to Bloom's mind:

Metempsychosis, he said, is what the ancient Greeks called it. They used to believe you could be changed into an animal or a tree, for instance. What they called nymphs, for example. (Joyce 1992, p. 79)

Just as Stephen had not wanted to expose his mood to his innocent pupils, so Bloom conceals the moment in which death breaks through denial and pushes itself to the front of his thoughts. Aristotle of course rejected the opinion that the soul could be separated from the body (De Anima II.1) but did believe it was incorruptible, and as we have seen with reference to Aquinas, the question of the survival of the soul could—just—-be opened up at that point. It seems likely in any case that, as a work, Ulysses steers away from the entelechy of the individual being into a version of metempsychosis, licensed 
presumably by a version of Viconian recursiveness, in which the individual is freely substitutable. Stephen turns over this possibility in Nestor as he teaches Pyrrhus' famous words of defeat to his class, noting to himself that the words free themselves of their occasion and might be spoken by "Any general to any officers" (Joyce 1992, p. 28), and it is one of the most striking phrases in Penelope which pushes substitutability front and centre when, in seeming to confirm her attachment to her husband, she remembers the thought that crossed her mind when she decided to marry him, "as well him as another" (Joyce 1992, p. 933), in weak affirmation.

If Stephen dwells on the human soul, Bloom is famously more cognisant of his own animality. This is clear from the first page of Calypso where the Blooms' cat is given voice- "Mkgnao"-leading Bloom to reverse the human-animal hierarchy found for example in Aquinas and assert to himself: "They understand what we say better than we understand them" and try to imagine the cat's perspective:

Wonder what I look like to her. Height of a tower? No, she can jump me. (Joyce 1992, pp. 65, 66)

This often-cited passage is held to evidence Bloom's capacity for sympathy and empathy, even between species, which is a running theme of the book even as the possibility and efficacy of seeing things from the point of view of the other is repeatedly called into question (viz. Bloom's even-handedness in Cyclops). Aristotle draws only certain distinctions between the human and other animals, and his conception of psyche applies to all animals and even in one of its aspects to plants. Aristotle does not propose a human/animal opposition in the way that it is sometimes said that traditional thinkers do. Jacques Derrida, for example, considers the habitual opposition of the human and animals to be a "violence" against animals, but although this opposition is widely found, to generalise this case may be a historical misrepresentation. The prime exhibit in this regard is Martin Heidegger's lecture course of 1929-1930, The Fundamental Concepts of Metaphysics. This lecture course was not published by Heidegger, but it is highly valued as a transitional text between Sein und Zeit and Einführung in die Metaphysik. One reason these lectures have been of such intense interest is their attempt to ground a theory of animal life with reference to the biological sciences. Jacques Derrida for example commented on these lectures at length in his own lecture course, La Bête et le souverain. Before turning back to Aristotle it helps to give a flavour of the argument in these lectures. Heidegger outlines his argument as follows:

[I]n order actually to unfold the question "What is world?" we must acquire an initial understanding of what we mean by "world" and what it is that we reserve this term for. We are undertaking the [...] comparative examination of stone, animal and man, according to which the stone is worldless, the animal is poor in world, and man world-forming, in order to provide this initial understanding. The perspective from which we shall make our comparison [...] is the specific relation that stone, animal and man has in each case toward world. [...] We shall begin our comparative analysis by starting from the middle, that is, by asking what it means to say that the animal is poor in world. (Heidegger 1995, p. 185)

This poverty of the animal consists in both having and not having a world, a curious contradiction, which Heidegger declares must stand even though the relation of animal to world and its supposed poverty must, he says, continue to remain a problem. (Heidegger 1995, pp. 272-73)

This text of Heidegger is a locus classicus and is perhaps the most notable example in the last hundred years of an attempt to maintain the philosophical difference between man and animal-that is, other animals, or beasts (but on Heidegger's early Aristotelian position on animals see Bailey 2016). Although Heidegger makes reference to biological science in these lectures, his foray into science can hardly be compared to that of Aristotle, who was principally a biologist and whose De Anima and related Metaphysics arise in large part from his work on animals. While Heidegger can be critiqued by defenders of animals, and while Derrida in his rhetorical anger allows for a modulated comparison 
of the treatment of animals with the holocaust (Derrida 2006, pp. 46-48), Aristotle cannot properly be accused of a careless or dualistic separation of the human and the animal. Aristotle it is true is sometimes in the frame for his definitions of man as zoon logon echon and zoon politikon-Derrida for example discusses Heidegger's disdain for the former phrase and Agamben's treatment of the latter in La bête et le souverain (Derrida 2008, pp. 418-19), and Agamben in Homo Sacer singles out the passage in Aristotle's Politics which makes the distinction between language and voice, where it is stated that only man possesses language (Agamben 1995, p. 11, quoting Politics 1253a 10-18).

However, Aristotle does not always treat that question in this way and his conception of anima - and of what we might broadly term animality-runs in a different direction in his Historia Animalium. This interesting and less-consulted text is much more inclined to include man among the animals than is suggested by those phrases from the Politics-which have become convenient soundbites or viral memes. It is worth highlighting, if not to say any more about them here, some of the passages in which Aristotle situates man as one of the animals. This passage for instance shows among other things how, as a biologist, Aristotle is interested in the process of classification, a reminder perhaps to read those phrases in the Politics as more a matter of classification than as metaphysical binaries. The passage has a passing interest too for the modelling of sovereignty in $\mathrm{La}$ Bête et le souverain:

The social animals are those which have some one common activity; and this is not true of all the gregarious animals. Examples of social animals are man, bees, wasps, ants, cranes. Some of them live under a ruler, some have no ruler; examples: cranes and bees live under a ruler, ants and innumerable others do not. Some of the gregarious and also some of the solitary animals remain in one situation, others roam about. (Aristotle 1965, p. 15)

When he comes to treat the question of the body-which is really the central question of $D e$ Anima-Aristotle takes man first, not because he privileges man, he claims, but just because that happens to be his own species:

And first, we should consider the parts of the human body. Every nation reckons currency with reference to the standard most familiar to itself; and we must do the same in other fields: man is, of necessity, the animal most familiar to us. (Aristotle 1965, p. 37)

In relation to voice and language, which was our starting point in relation to Bloom's cat, man is once again situated among the animals:

Again, some emit a noise, some are mute; some have a voice; and of the latter some are articulate and others inarticulate; some are always chattering, some tend to be quiet; some are tuneful, some are not. But it is common to all of them to sing or chatter most of all about the time of mating. (Aristotle 1965, p. 17)

The discussion of logos from the Politics does not appear here at all. "Voice differs from sound, and speech from both" (Aristotle 1970, p. 73), he notes before going on to discuss how animals without lungs make sounds, and then turning to man and mammals. Here he does indeed draw a distinction:

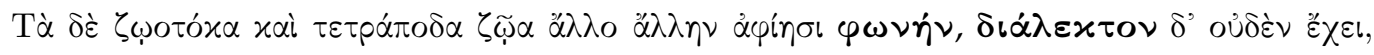

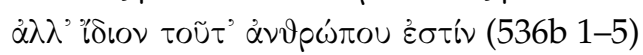

The different viviparous quadrupeds utter different voices, but they have no power of speech; this power is peculiar to man. (Aristotle 1970, p. 81)

Here, we should note the use of dialekton, but not logos, with all the sense the latter might carry of language, definition, and related notions. The translator here has used the term "power of speech" and in the ensuing treatment of the topic the term recurs:

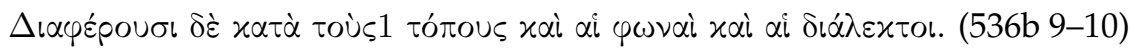


Voices and modes of speech differ according to locality.

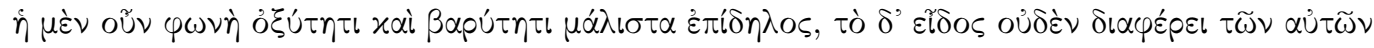

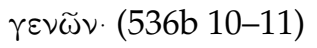

Voice is distinguished chiefly by its pitch, high or low; it does not differ in kind in one and the same sort of animal. (Aristotle 1970, p. 83)

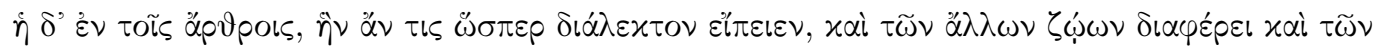

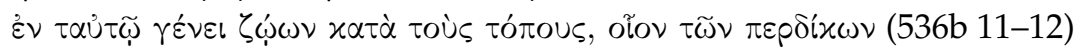

But articulated voice, which one might describe as a sort of "speech," differs in different animals, and also within one and the same kind of animal according to locality. (Aristotle 1970, p. 83)

Having described the different voices of the partridge and reported the observation that the hen teaches song to its chicks Aristotle notes:

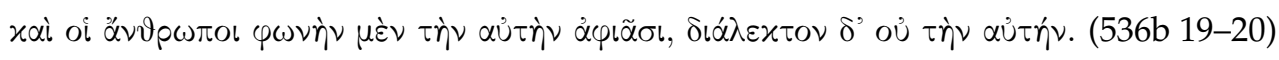

Men have the same voice the world over, but different varieties of speech. (Aristotle 1970, p. 83)

All we are noting here is that questions of logos do not arise, even if the term dialekton-which the translator resolutely refuses to render as "dialect", a term which other translators also avoid-introduces a strange ambiguity as to where dialekton lies, though it seems to veer strongly towards the conception of a regional language, one among a plurality.

At the conclusion of the essay of the same title, Derrida writes in L'animal que donc je suis:

Je voudrais donner à entendre le pluriel d'animaux dans le singulier; il n'y a pas l'Animal au singulier général, séparé de l'homme par une seule limite indivisible. Il faut envisager qu'il y ait des "vivants" dont la pluralité ne se laisse pas rassembler dans la seule figure de l'animalité simplement opposée à l'humanité. (Derrida 2006, p. 73)

I wanted to suggest the plural of animals in the singular; there is no singular Animal, separated from man by a single indivisible limit. We have to think that there are "living things" whose plurality can't be brought together and the single figure of animality as opposed to man. (My translation)

He adds:

Il ne s'agirait pas de "rendre la parole" aux animaux mais peut-être accéder à une pensée, si chimérique ou fabuleuse soit-elle, qui pense autrement l'absence du nom ou du mot, et autrement comme une privation. (Derrida 2006, p. 74)

It isn't a matter of giving animals a turn to speak but perhaps of allowing the thought, as chimerical and fabulous as it may be, which thinks otherwise the absence of the name or the word, and other than as a privation. (My translation)

It should be clear from what we have seen of Historia Animalium that Aristotle was already in this position of seeking models of classification, not erecting binaries, and we have argued that this way of thinking is inherent in his exposition of the psyche or anima. We can see the Aristotle of Aquinas at work in Stephen's thoughts on identity and death, but we can see an Aristotle without medieval accretions at work in Bloom's exchange with the cat. In contrast to the pessimism of the biopolitics of Foucault and Agamben, which represents the innocence and pleasure in living (euemeria) of zoe as 
subordinated to the sovereignty of ever more tightly-binding bios, the Joyce/Aristotle axis appears to open on to an account of life and living through a route other than the systemically ruined subject.

In a talk entitled "De l'âme", now printed as a supplement to the volume Corpus Jean-Luc Nancy states simply:

Why did I give my talk this title? I was asked to speak about the body so I am going to speak about the soul. Such a title makes for an interruption, a break. On the Soul is the title of a famous treatise by Aristotle. And in that treatise Aristotle speaks of nothing but the body. So my premise is this. The soul is not just another body, a little person, as in the traditional iconography. Instead-as we see in Aristotle, Thomas, even in Spinoza and Descartes as surprising as this may seem-the body is not something other than the body but the body outside itself, what the body is for-itself and in-itself, as a structure. So we have to use the term "soul" even if this creates a lot of ambiguity. "On the soul" means "on the relationship of the body with itself". (excerpted and freely translated from (Nancy 2006, pp. 112-14))

Conflicts of Interest: The author declares no conflict of interest.

\section{References}

Agamben, Giorgio. 1995. Homo Sacer: Il Potere Sovrano E La Nuda Vita. Torino: Einaudi.

d'Aquin, Thomas. 2016. L'Âme Et Le Corps: Somme De Théologie, Première Partie, Questions 75 et 76. Introduction by Bernardo Carlos Bazan; Translated by Jean-Baptiste Brenet. Paris: Vrin.

Aristotle. 1957. On the Soul. Parva Naturalia. On Breath. Loeb Classical Library 288; Translated by W.S. Hett. Cambridge: Harvard University Press.

Aristotle. 1965. History of Animals, Volume I: Books 1-3. Loeb Classical Library 437; Translated by A.L. Peck. Cambridge: Harvard University Press.

Aristotle. 1970. History of Animals, Volume II: Books 4-6. Loeb Classical Library 438; Translated by A.L. Peck. Cambridge: Harvard University Press.

Bailey, Christiane. 2016. Affection, comprehension et langage: L'être-au-monde animal dans les interpretations phénoménologiques d'Aristote du jeune Heidegger. In Phénoménologie de la Vie Animale. Edited by Florence Burgat and Cristian Ciocan. Bucarest: Zeta, pp. 121-58.

Bazán, Bernardo Carlos. 2016. Esquisse d'une anthropologie philosophique selon Thomas d'Aquin. In L'Âme Et Le Corps: Somme De Théologie, Première Partie, Questions 75 et 76. Introduction by Bernardo Carlos Bazan; Translated by Jean-Baptiste Brenet. Paris: Vrin.

Derrida, Jacques. 1963. Force et Signification. In L'Écriture et la Différance. Paris: Seuil, pp. 9-49.

Derrida, Jacques. 1987. La main de Heidegger (Geschlecht II) (1984-1985). In Psyché: Inventions de L'autre. Paris: Galilée, pp. 415-51.

Derrida, Jacques. 2006. L'Animal Que Donc Je Suis. Edited by Marie-Louise Mallet. Paris: Galilée.

Derrida, Jacques. 2008. Séminaire: La Bête et le Souverain. Volume I. Edited by Michel Lisse, Marie-Louise Mallet and Ginette Michaud. Paris: Galilée.

Jacques Derrida, and Gianni Vattimo, eds. 1996. La Religion: Séminaire de Capri. Paris: Minuit.

Heidegger, Martin. 1995. The Fundamental Concepts of Metaphysics: World, Finitude, Solitude. Translated by William McNeill, and Nicholas Walker. Bloomington and Indianapolis: Indiana University Press.

Heidegger, Martin. 2000. Introduction to Metaphysics. Translated by Gregory Fried, and Richard Polt. New Haven and London: Yale.

Henry, Michel. 1963. L'Essence de la Manifestation. Paris: PUF.

Henry, Michel. 1996. C'est Moi La Verite, Pour Une Philosophie Du Christianisme. Paris: Seuil.

Henry, Michel. 2000. Incarnation: Une Philosophie De La Chair. Paris: Seuil.

Henry, Michel. 2003. Le concept de l'âme, a-t-il un sens? In Phénoménologie De La Vie I: De la Phénoménologie. Paris: PUF, pp. 9-38.

Janicaud, Dominique. 1991. Le Tournant Theologique De La Phenomenologie Française. Combas: L'éclat. 
Janicaud, Dominique, François Courtine, Jean-Louis Chrétien, Michel Henry, Jean-Luc Marion, and Paul Ricoeur. 2000. Phenomenology and the Theological Turn: The French Debate. New York: Fordham University Press.

Joyce, James. 1992. Ulysses: Annotated Student's Edition. Introduction and Notes by Declan Kiberd; London: Penguin. Lawson-Tancred, Hugh. 1986. Introduction. In Aristotle, De Anima (On the Soul). Translated with introduction and Notes by Hugh Lawson-Tancred; London: Penguin.

Lernout, Geert. 2010. Help My Unbelief: James Joyce and Religion. New York: Continuum.

Mak, Cliff. 2016. Joyce's Indifferent Animals: Boredom and the Subversion of Fables in Finnegans Wake. Modernist Cultures 11: 179-205. [CrossRef]

Marion, Jean-Luc. 1982. Dieu Sans L'être. Paris: Fayard.

Marion, Jean-Luc. 1997. Etant Donne: Essai D'une Phenomenologie De La Donation. Paris: PUF.

Nancy, Jean-Luc. 2006. Corpus. Paris: Métailié.

Noon, William T. 1957. Joyce and Aquinas. New Haven and London: Yale University Press.

Norris, Margot. 2014. The Animals of James Joyce's Finnegans Wake. Modern Fiction Studies 60: 527-43. [CrossRef] O'Rourke, Fran. 2011. Joyce's Early Aesthetic. Journal of Modern Literature 34: 97-120. [CrossRef]

Polansky, Ronald. 2007. Aristotle's De Anima: A Critical Commentary. Cambridge: Cambridge University Press.

Schork, R. J. 1998. Greek and Hellenic Culture in Joyce. Gainesville: University Press of Florida.

Tonning, Erik. 2014. Modernism and Christianity. Basingstoke: Palgrave Macmillan.

(c) 2017 by the author. Licensee MDPI, Basel, Switzerland. This article is an open access article distributed under the terms and conditions of the Creative Commons Attribution (CC BY) license (http://creativecommons.org/licenses/by/4.0/). 